\title{
Cropping Systems and their Diversity in Khulna Region
}

\author{
M Harunur Rashid ${ }^{1 *}$, B J Shirazy ${ }^{1}$, M Ibrahim² ${ }^{2}$ and S M Shahidullah ${ }^{1}$
}

\begin{abstract}
This study includes the existing cropping pattern, cropping intensity and crop diversity of Khulna region. A pre-designed and pre-tested semi-structured questionnaire was used to collect the information and validated through organizing workshop. Single T. Aman cropping pattern was the most dominant cropping pattern in Khulna region existed in 17 out of 25 upazilas. Boro-Fallow-T. Aman cropping pattern ranked the second position distributed almost in all upazilas. Boro-Fish was the third cropping pattern in the region distributed to 17 upazilas with the major share in Chitalmari, Dumuria, Rupsha, Tala, Kalaroa, Mollahat, Terokhada, Bagerhat sadar, Fakirhat, Rampal and Phultala upazilas. Single Boro rice was recorded as the fourth cropping pattern covered 18 upazilas with the higher share in waterlogged area of Dumuria, Mollahat, Tala, Bagerhat sadar, Fakirhat and Rampal. The highest number of cropping patterns was recorded in Kalaroa (26) followed by Tala (24) and the lowest was reported in Mongla (5). The overall crop diversity index (CDI) for the region was 0.93 . The highest CDI was in Tala (0.95) and the lowest in Dacope (0.42). The average cropping intensity (CI) of the Khulna region was 171\% with the lowest in Mongla (101\%) and the highest in Kalaroa (224\%).
\end{abstract}

Key words: Cropping intensity, diversity index, land use, rice-fish, and soil salinity

\section{INTRODUCTION}

Large number of crops are grown under different cropping pattern in different parts of Bangladesh with a variability from a region to another. Greater Khulna consists of both saline and non-saline ecosystems. Agriculture of this region is mainly dominated by rice and fish (shrimp and others). Year round vegetable cultivation as a dyke cropping is also frequently observed in Rice-Fish system for both ecosystems.

A cropping pattern is defined as yearly sequences of crop production in a piece of land (Alam, 1994). It depends on physical, historical, social, institutional and economic factors as well as government policies (Agrawal and Kassam, 1976). The cropping pattern and the changes therein depend on a large number of factors like climate, soil type, rainfall, pest pressure, availability of technologies; availability of irrigation facilities and other inputs, marketing and transport facilities, subsistence pressure and the growth of agro-industries (Neema, 1998; Gadge, 2003; Rashid et al., 2005).

The coastal districts of the country have generally been identified as a disadvantaged region in terms of poverty, food insecurity, environmental vulnerability and limited livelihood opportunities. The Master Plan for Agricultural Development in the Southern Region of Bangladesh focused on increasing agricultural productivity and improving water management and rejuvenating productivity of degraded lands (MoA and FAO, 2013). Agricultural land use in the coastal districts is very poor. The average cropping intensity of the country was $179 \%$ in $2007-08$, whereas it is $128-147 \%$ in southern districts (BBS, 2014). The major part of this region is affected by different gradient of salinity. The low land use in the region is mainly due to salinity and peculiar hydrology, waterlogging in Kharif II and early Rabi season and lack of quality irrigation water

${ }^{1}$ Rice Farming Systems Division, BRRI, Gazipur; ${ }^{2 B R R I ~ R S ~ S a t k h i r a ; ~ * C o r r e s p o n d i n g ~ a u t h o r ' s ~ E-m a i l: ~ h r a s h i d 67 @ y a h o o . c o m ~}$ 
(drought) in Rabi and Kharif I seasons, and tidal storm (Rahman and Ahsan, 2011). The southwestern part, Khulna, Bagerhat and Satkhira districts are the worst hit by water and soil salinity (SRDI, 2010). The stress environment of the southern part of the country received very little attention in the past. The increased pressure of growing population demand more food that brings attention to explore the possibilities of increasing the potential of the saline lands for increased production of crops. Moreover, cultivable land area is decreasing day by day in the country. In this context, there is no other alternative but to address less favourable and unfavourable environments for food security and to adapt to the climatic variability.

The increased total system productivity of an environment needs diversity in enterprises for better utilization of limited resources. A detail information on land situation and cropping systems is a pre-requisite for a fruitful development programme. The Directorate of Agricultural Extension maintains a statistics on individual crop at upazila level. However, there is limited information on cropping pattern and cropping intensity at upazila and regional level. Understanding the present scenario of cropping patterns of a particular area may guide policy makers, researchers and extension personnel for taking initiative to fulfill the implementation of priority plan of Sustainable Development Goal and Seventh Five year Plan for ending poverty and achieving food security. The specific objectives of the study were to:

- Understand the existing cropping patterns scenario in Khulna region.

- Visualize the existing land use pattern at upazila and regional level.

- Determine the crop diversity and cropping intensity at upazila, district and regional level.

\section{METHODOLOGY}

Twenty-five upazilas of Khulna, Satkhira and Bagerhat districts under Khulna agricultural region were the locale of this study. Data were collected using double stage procedure. At initial stage, data were collected through pretested semi-structured questionnaire from 25 pre-assigned Sub-Assistant Agriculture Officers (SAAO) of each upazila during January 2016 at upazila level. The SAAOs were purposively preselected by Agriculture Extension Officers (AEO), Additional Agriculture Officer (AAO) and Upazila Agriculture Officer (UAO) or altogether. Prior to data collection, the pretested questionnaire was explained along with proper guidelines to the AEOs or UAOs or both and handed over to them at each Deputy Director's office of Directorate of Agricultural Extension (DAE) during monthly meeting for the sake of accurate data collection. The filled questionnaires were collected by the scientists of RFS Division, checked and analyzed to find the inconsistencies of the supplied data before validation workshop. All the inconsistencies among the information were documented. The collected data along with documented inconsistencies were discussed in district level workshop to for necessary correction and validation. Second stage of data collection was daylong data validation workshop at district level. The workshop dates were 29 March for Khulna; 31 March for Bagerhat; and 11 April 2016 for Satkhira. Four field-workers i.e. one SAPPO and three SAAOs experienced and engaged in crop-based data documentation, all officers from all upazilas viz UAOs, AEOs, AAEOs, DD (DAE), DD (Horticulture), DD of Seed Certification Agency, DTO and ADDs, one representative from Agricultural Training Institute (ATI) and scientists of BRRI regional station, Satkhira participated in the data validation workshop. The number of participants of validation workshop ranged from 58 to 95 in each district. All the participants were divided into three to four groups for data validation. Each group was facilitated by two RFSD scientists to finalize and validate the data and authenticated data were captured. Crop diversity index was calculated by using the following equation described by Kshirsagar et al. (1997).

$$
C D I_{i}=1-\sum_{j=o}^{n}\left(\frac{a_{i j}}{A_{i}}\right)^{2}
$$


Where, $\mathrm{CDI}_{\mathrm{i}}=$ Crop Diversity Index

$a_{i j}=$ Area planted to the $j^{\text {th }}$ crop in the $i^{\text {th }}$ location

$\mathrm{A}_{\mathrm{i}}=$ Total area planted under all crops

The index is zero for a land area growing only one crop approaches unity as the level of diversity increase. Compilation and processing of collected data were done using Micro Soft Excel programme. Descriptive statistics were used to facilitate the presentation of the findings.

\section{RESULTS AND DISCUSSION}

\section{Land use}

Crops occupied the particular land for round the year were considered under annual crops. The major annual crops reported in the region were sugarcane, banana and papaya. The annual crops area in different upazilas ranged nil to 870 ha. The annual crops area accounted only $1.75 \%$ of the net cropped area (NCA) in the region. The single cropped area (SCA) had the major share of NCA in Mongla, Morrelganj, Rampal and sadar upazila of Bagerhat district; Dacope and Koyra upazilas of Khulna district and Shyamnagar upazila of Satkhira district followed by corresponding double cropped area (DCA). The rest of the upazilas were dominated by DCA (Table 1). The proportion of triple cropped area (TCA) were higher than SCA in Debhata, Kalaroa and sadar upazilas of Satkhira district. The quadruple cropped area was only reported in Kalaroa upazila. The SCA, DCA, TCA in the region were $36.4 \%$, $51.4 \%$ and $9.6 \%$ of the NCA. The area which could not be defined under SCA, DCA, TCA or QCA was considered as other. The average cropping intensity (CI) of the Khulna region was $171 \%$ with the lowest in Mongla (101\%) and the highest in Kalaroa (224\%).

\section{Cropping patterns of Khulna}

In total 92 cropping patterns were observed in Khulna region of which nine cropping patterns with exclusive rice crop covers about $63 \%$ of the NCA. There were 16 cropping patterns with exclusive non-rice crop covering over $4 \%$ of the NCA. Rest of the NCA i.e. around 33\% area is covered by 67 rice - non rice cropping patterns (Appendix 1).

\section{Exclusive rice crops}

In Khulna region, most of the area (about $63 \%)$ was covered by exclusively rice-based cropping pattern (Table 2). The highest area coverage $(26.76 \%)$ was occupied by single $\mathrm{T}$. Aman cropping pattern and was reported in 17 upazilas out of 25. Boro-Fallow- T. Aman cropping pattern covered $22.21 \%$ area which was next to single T. Aman cropping pattern but existed in the highest number of upazilas (24). Single Boro covered $7.69 \%$ area and was reported in 18 upazilas followed by BoroAus-Fallow (2.12\%) in eight upazilas. Other cropping patterns were Boro-Aus-T. Aman, Fallow-B. Aman and, Fallow-B. Aus + T. Aman.

\section{Exclusive non-rice crops}

Year round vegetables cultivation were found in most of the upazilas with the total coverage of $3.33 \%$. Vegetables cultivated both in Rabi and Kharif-I seasons found in 10 upazilas whereas vegetables grown in Rabi season only in three upazilas with very less area coverage (Table 3).

In the current investigation, 16 cropping patterns were identified without rice. Among these 16 patterns; first eight have been arranged in descending order in Table 3. The rest eight patterns with negligible area coverage in Table 7 are arranged with other patterns of different categories. Aggregate of the 16 patterns have had $4.53 \%$ of NCA. In critical comparison it is clear that exclusive rice area is about 14 folds of exclusive non-rice area. In the major areas of Khulna region salinity is the main constraint against the diversification of crops and cropping patterns. The rapid increase in human population creates additional pressure on natural resources at above optimal levels of their inherent potential, which resulted the loss of biodiversity, serious soil erosion leading to depletion of plant nutrient, gradual degradation and decline in productivity and 
Table 1. Upazila-wise land utilization and cropping intensity of Khulna region, 2014-15.

\begin{tabular}{|c|c|c|c|c|c|c|c|c|c|c|}
\hline & Upazila & $\begin{array}{r}\text { Area of } \\
\text { upazila (ha) }\end{array}$ & $\begin{array}{r}\text { Annual } \\
\text { crop (ha) }\end{array}$ & SCA (ha) & DCA (ha) & $\begin{array}{r}\text { TCA } \\
\text { (ha) }\end{array}$ & $\begin{array}{r}\text { QCA } \\
\text { (ha) }\end{array}$ & $\begin{array}{r}\text { Other } \\
\text { (ha) }\end{array}$ & NCA (ha) & C.I. $(\%)$ \\
\hline 01 & Bagerhat sadar & 31356 & 750 & 6700 & 6330 & 2680 & 0 & 190 & 16650 & 171 \\
\hline 02 & Chitalmari & 19206 & 20 & 1010 & 11340 & 990 & 0 & 160 & 13520 & 200 \\
\hline 03 & Fakirhat & 15890 & 500 & 3100 & 4380 & 710 & 0 & 110 & 8800 & 167 \\
\hline 04 & Kachua & 12351 & 430 & 1700 & 6040 & 810 & 0 & 150 & 9130 & 185 \\
\hline 05 & Mollahat & 17682 & 870 & 4300 & 9540 & 1310 & 0 & 150 & 16170 & 176 \\
\hline 06 & Mongla & 18242 & 0 & 2570 & 80 & 0 & 0 & 50 & 2700 & 103 \\
\hline 07 & Morrelganj & 44580 & 800 & 19090 & 6420 & 1240 & 0 & 150 & 27700 & 132 \\
\hline 08 & Rampal & 27644 & 0 & 6300 & 2840 & 200 & 0 & 60 & 9400 & 135 \\
\hline 09 & Sarankhola & 15129 & 60 & 3800 & 4780 & 700 & 0 & 120 & 9460 & 166 \\
\hline 10 & Batiaghata & 23622 & 20 & 5500 & 11740 & 500 & 0 & 110 & 17870 & 172 \\
\hline 11 & Dacope & 28557 & 120 & 16100 & 2260 & 160 & 0 & 130 & 18770 & 114 \\
\hline 12 & Dighalia & 8655 & 220 & 1200 & 4110 & 140 & 0 & 50 & 5720 & 177 \\
\hline 13 & Dumuria & 45423 & 50 & 11200 & 15960 & 2160 & 0 & 130 & 29500 & 169 \\
\hline 14 & Phultala & 7438 & 80 & 515 & 3955 & 220 & 0 & 110 & 4880 & 192 \\
\hline 15 & Koyra & 26323 & 80 & 10680 & 4310 & 395 & 0 & 115 & 15580 & 133 \\
\hline 16 & Paikgachha & 39302 & 160 & 3700 & 12420 & 710 & 0 & 120 & 17110 & 181 \\
\hline 17 & Rupsha & 12025 & 210 & 2020 & 5640 & 200 & 0 & 90 & 8160 & 175 \\
\hline 18 & Terokhada & 18769 & 140 & 4000 & 5100 & 120 & 0 & 130 & 9490 & 157 \\
\hline 19 & Assasuni & 37660 & 0 & 4500 & 5960 & 920 & 0 & 120 & 11500 & 169 \\
\hline 20 & Debhata & 17305 & 10 & 740 & 3870 & 2000 & 0 & 190 & 6810 & 219 \\
\hline 21 & Kalaroa & 23150 & 230 & 1000 & 10890 & 5160 & 110 & 140 & 17530 & 224 \\
\hline 22 & Kaliganj & 33178 & 560 & 5000 & 11070 & 1690 & 0 & 140 & 18460 & 179 \\
\hline 23 & Satkhira sadar & 40758 & 110 & 1000 & 18930 & 6760 & 0 & 110 & 26910 & 221 \\
\hline 24 & Shyamnagar & 199099 & 90 & 12000 & 4830 & 450 & 0 & 120 & 17490 & 133 \\
\hline \multirow[t]{2}{*}{25} & Tala & 33726 & 830 & 4010 & 13270 & 4390 & 0 & 230 & 22730 & 198 \\
\hline & Khulna region & 797070 & 6340 & 131735 & 186065 & 34615 & 110 & 3175 & 362040 & 171 \\
\hline
\end{tabular}

Table 2. Cropping patterns with exclusive rice in Khulna region, 2014-15.

\begin{tabular}{llrrr}
\hline & Cropping pattern & Area (ha) & \% of NCA & Frequency (no. of upazila) \\
\hline 1 & Fallow-Fallow-T. Aman & 96900 & 26.76 & 17 \\
2 & Boro-Fallow-T. Aman & 80420 & 22.21 & 24 \\
3 & Boro-Fallow-Fallow & 27850 & 7.69 & 18 \\
4 & Boro-Aus-Fallow & 7670 & 2.12 & 8 \\
5 & Boro-Aus-T. Aman & 3895 & 1.08 & 12 \\
6 & Fallow-B.Aman & 3520 & 0.97 & 4 \\
7 & Boro-B.Aman & 3500 & 0.97 & 4 \\
8 & Fallow-Aus-T. Aman & 2220 & 0.61 & 6 \\
9 & Fallow-B.Aus+B.Aman & 400 & 0.11 & 1 \\
\hline & Total & 226375 & 62.53 & - \\
\hline
\end{tabular}

Table 3. Cropping pattern with exclusive non-rice in Khulna region, 2014-15.

\begin{tabular}{llcc}
\hline Cropping pattern & Area (ha) & \% of NCA & Frequency (no. of upazila) \\
\hline 01 Vegetables-Vegetables-Vegetables & 12060 & 3.33 & 23 \\
02 Vegetables-Vegetables-Fallow & 2420 & 0.67 & 10 \\
03 Vegetables-Fallow-Fallow & 535 & 0.15 & 3 \\
04 Chilli-Vegetab-Fallow & 340 & 0.09 & 8 \\
05 Potato-Jute-Fallow & 250 & 0.07 & 1 \\
06 Mustard-Jute-Fallow & 200 & 0.06 & 1 \\
07 W.Melon-Fallow-Fallow & 200 & 0.06 & 1 \\
08 Potato-Chilli-Fallow & 100 & 0.03 & 1 \\
09-16 Other eight patterns (in Table 7) & 300 & 0.08 & - \\
\hline Total & 16405 & 4.53 & - \\
\hline
\end{tabular}


carrying capacity, etc. Even though appropriate cropping patterns may facilitate maximum possible land utilization as well as efficient use of other scarce resources in a sustainable manner. Diversified cropping pattern may be an option for the farmers as a coping strategy against risks (Mandal and Bezbaruah, 2013). Typology of different cropping systems is the base for the managers of these systems to intensify production (Shriar, 2000).

\section{Rice-Fish culture}

Rice-Fish system occupied $16.41 \%$ of the NCA in the region. The waterlogged ghers create opportunity for practicing rice-fish in large area. Under the rice-fish system, the highest area was under Boro-Fsh cropping pattern (8.67\%) and was also extensive (17 upazilas) followed by Fish-T. Aman cropping pattern (5.63\%) reported in eight upazilas (Table 4). Boro-Fallow-T. Aman + Fish and Fallow-Fallow-T. Aman + Fish were found in seven and two upazilas covered 1.49 and $0.61 \%$ of NCA, respectively. There is a general practice of seasonal and year round cultivation of vegetables on the bank of the field. Proper attention on this enterprise might uplift the total productivity of the system. Modern agricultural technology along with increased marketing facilities can fulfill this need.

\section{Pulse crops}

Eighteen cropping patterns are holding different pulse crops (Table 5). Among them grasspea is covering the largest area. In contrast, chickpea is cultivated in the smallest area. Seven cropping patterns of grasspea jointly cover about three-fourths of the pulse crop area. Lentil holds the second position in pulse crop cultivation in Khulna region. There are seven cropping patterns for lentil also where Lentil-Jute-T. Aman is the most dominant. In the documentation of pulse cropping grasspea reported its widest spreading in the region. One pattern is available in 11 upazilas and the second one exists in six upazilas both are grasspea based. Finally the aggregate area of the pulse cropping system stands for $3.59 \%$ of the NCA in Khulna region.

\section{Oil-seed crops}

Sesame, mustard and sunflower are the oilseed crops grown in the Khulna region. Among them, sesame is the most important one among the oil-seed crops in the region. There are 18 cropping patterns for oil-seeds of which eight

Table 4. Cropping patterns with rice and fish in Khulna region, 2014-15.

\begin{tabular}{llrrr}
\hline & Rice-Fish & Area (ha) & \% of NCA & Frequency (no. of upazila) \\
\hline 1 & Boro-Fish & 31400 & 8.67 & 17 \\
2 & Fish-T. Aman & 20400 & 5.63 & 8 \\
3 & Boro-Fallow-T. Aman+Fish & 5410 & 1.49 & 7 \\
4 & Fallow-Fallow-T. Aman+Fish & 2200 & 0.61 & 2 \\
\hline & Total rice-fish & 59410 & 16.41 & - \\
\hline
\end{tabular}

Table 5. Area coverageof pulse crops under different cropping systems in Khulna region, 2014-15.

\begin{tabular}{llcc}
\hline Cropping pattern & Area (ha) & \% of NCA & Frequency (no. of upazila) \\
\hline 01 Grasspea-Fallow-T. Aman & 8390 & 2.32 & 11 \\
02 Lentil-Jute-T. Aman & 1390 & 0.38 & 5 \\
03 Mungbean-Fallow-T. Aman & 1280 & 0.35 & 8 \\
04 Grasspea-Jute-T. Aman & 780 & 0.22 & 6 \\
05 Grasspea-Aus-T. Aman & 350 & 0.10 & 1 \\
06 Lentil-Fallow-T. Aman & 280 & 0.08 & 6 \\
07 Grasspea-Mungbean-T. Aman & 170 & 0.05 & 2 \\
08 Boro-Fallow-Blackgram & 100 & 0.03 & 1 \\
09 Lentil-Sesame-T. Aman & 50 & 0.01 & 1 \\
10-18 Other nine patterns (in Table 7) & 200 & 0.06 & - \\
\hline Total pulse crops & 12990 & 3.59 & \\
\hline
\end{tabular}


patterns had been led by sesame alone (Table 6 and Table 7). The total share of oil-seed cropping patterns is $5.21 \%$ of NCA whereas sesame absolutely occupies about 3\%. The second prevailing mustard covers over $2 \%$. However, the dominance of oil-seed crops and its spreading over the region are not running in the same direction. Sunflower, with its third largest coverage, had been widely spread out over 11 upazilas.

\section{Sporadic and distinct cropping patterns}

There are some cropping patterns which are extremely location-specific, however, with a large area coverage. These are F-Jute-T. Aman, Boro-Jute-F (Appendix 1) and F-F-T. Aman+Fish (Table 4). The F-Jute-T. Aman is grown on 1,100 ha only in Kalaroa of Satkhira district. Boro-Jute-F is cultivated in Dumuria upazila (1,500 ha) of Khulna district and in Tala upazila (1,300 ha) of Satkhira district. Fallow-Fallow-T. Aman+Fish is practiced in Mongla (300 ha) of Bagerhat and in Dumuria (1,900 ha).

\section{Rare cropping patterns}

In the present investigation, 30 cropping patterns have been identified as rare cropping patterns with a negligible area coverage with seldom existence (Table 7). These are location specific system and are limited in one to four upazilas of the region. Total area coverage of the 30 patterns is far less than 1\% of NCA. Among them the highest area was coverd by Boro-
Fallow-Blackgram, Potato-Chilli-Fallow and Wheat-Fallow-T. Aman (100 ha for each). The smallest area was recorded for 10 cropping patterns whose coverage was 10 hectares for each (Table 7).

\section{Most dominant cropping pattern}

Single T. Aman cropping pattern was the most dominant cropping with 96,900 ha coverage in Khulna region in 17 upazilas, namely, Morrelganj, Dacope, Shyamnagar, Koyra, Batiaghata, Kaliganj, Dumuria, Rampal, Assasuni, Bagerhat sadar, Sarankhola, Paikgachha, Mongla, Rupsha, Kachua, Fakirhat and Debhata. The contribution of these upazilas in the existence of the cropping pattern ranged 0.10 to $19.30 \%$ in the region. The higher area coverage under this cropping pattern werein Morrelganj, Dacope, Shyamnagar, Koyra, Batiaghata, Kaliganj and Dumuria. On the other hand, the least area coverage was reported in Debhata, Fakirhat and Kachua (Table 8). Diversified cropping pattern may be resort for the farmer as a coping strategy with flood related risk (Mandal and Bezbaruah, 2013) but scope of diversification is limited due to environmental and climatic condition (FAO, 1988). In the country-wide data compilation it was observed that the single T. Aman was the $3^{\text {rd }}$ dominant cropping pattern in Bangladesh covering 5.09 lac ha (6\% of NCA in the country) with its distribution in 162 upazilas of 36 districts (Nasim et al., 2017).

Table 6. Area coverage of oil-seed crops under different cropping systems in Khulna region, 2014-15.

\begin{tabular}{llcc}
\hline Cropping pattern & Area (ha) & \% of NCA & Frequency (no. of upazila) \\
\hline 01 Fallow-Sesame-T. Aman & 10170 & 2.81 & 8 \\
02 Mustard-Jute-T. Aman & 3210 & 0.89 & 4 \\
03 Mustard-Boro-T. Aman & 2470 & 0.68 & 4 \\
04 Mustard-Fallow-T. Aman & 940 & 0.26 & 9 \\
05 Sunflower-Fallow-T. Aman & 490 & 0.14 & 11 \\
06 Mustard-Aus-T. Aman & 450 & 0.12 & 1 \\
07 Mustard-Sesame-T. Aman & 310 & 0.09 & 1 \\
08 Mustard-Aus-Fallow & 200 & 0.06 & 1 \\
09 Mustard-Jute-Fallow & 200 & 0.06 & 1 \\
10 Mustard-Boro-Jute-T. Aman & 110 & 0.03 & 1 \\
11 Potato-Sesame-T. Aman & 70 & 0.02 & 1 \\
12 -18 Other seven patterns (in Table 7) & 245 & 0.07 & - \\
\hline
\end{tabular}


Table 7. Rare cropping patterns covering non-significant area in Khulna region, 2014-15.

\begin{tabular}{|c|c|c|c|c|c|}
\hline & Cropping pattern & Area (ha) & $\%$ of NCA & Frequency & Upazila \\
\hline 01 & Boro-Fallow-Blackgram & 100 & 0.03 & 1 & Tala \\
\hline 02 & Potato-Chilli-Fallow & 100 & 0.03 & 1 & Satkhira sadar \\
\hline 03 & Wheat-Fallow-T. Aman & 100 & 0.03 & 4 & Mollahat+Rupsha+Assasuni+Tala \\
\hline 04 & Coriander-Fallow-Fallow & 80 & 0.02 & 4 & Chitalmari+Morrelg.+Debhata+Tala \\
\hline 05 & Potato-Sesame-T. Aman & 70 & 0.02 & 1 & Tala \\
\hline 06 & Chilli-Fallow-Fallow & 50 & 0.01 & 2 & Mongla+Koyra \\
\hline 07 & Groundnut-Fallow-T. Aman & 50 & 0.01 & 1 & Dighalia \\
\hline 08 & Lentil-Sesame-T. Aman & 50 & 0.01 & 1 & Chitalmari \\
\hline 09 & Onion-Vegtab-Vegetab & 50 & 0.01 & 2 & Bagerhat sadar+Assasuni \\
\hline 10 & Wheat-Mungbean-T. Aman & 40 & 0.01 & 2 & Phultala+Tala \\
\hline 11 & Wheat-Vegetab-Vegetab & 40 & 0.01 & 1 & Koyra \\
\hline 12 & Boro-Sesbania-T. Aman & 30 & 0.01 & 2 & Dighalia+Terokhada \\
\hline 13 & Grasspea-Jute-Fallow & 30 & 0.01 & 1 & Kalaroa \\
\hline 14 & Lentil-Vegetab-T. Aman & 30 & 0.01 & 1 & Tala \\
\hline 15 & Mungbean-Jute-T. Aman & 30 & 0.01 & 1 & Debhata \\
\hline 16 & Onion-Sesame-T. Aman & 30 & 0.01 & 1 & Tala \\
\hline 17 & Potato-Mungbean-T. Aman & 30 & 0.01 & 2 & Assasuni+Kalaroa \\
\hline 18 & Sunflower-Jute-Fallow & 30 & 0.01 & 1 & Citalmari \\
\hline 19 & Wheat-Sesame-T. Aman & 30 & 0.01 & 1 & Tala \\
\hline 20 & Sesame-Fallow-T. Aman & 25 & 0.01 & 2 & Dacope+Phultala \\
\hline 21 & Boro-Jute-T. Aman & 10 & 0.00 & 1 & Bagerhat sadar \\
\hline 22 & Chickpea-Jute-T. Aman & 10 & 0.00 & 1 & Kalaroa \\
\hline 23 & Coriander-Fallow-T. Aman & 10 & 0.00 & 1 & Fakirhat \\
\hline 24 & Coriander-Jute-T. Aman & 10 & 0.00 & 1 & Kalaroa \\
\hline 25 & Coriander-Vegetab-Fallow & 10 & 0.00 & 1 & Kalaroa \\
\hline 26 & Grasspea-B.Aman & 10 & 0.00 & 1 & Dighalia \\
\hline 27 & Lentil-Aus-T. Aman & 10 & 0.00 & 1 & Kachua \\
\hline 28 & Lentil-B.Aman & 10 & 0.00 & 1 & Dighalia \\
\hline 29 & W.Melon-Aus-T. Aman & 10 & 0.00 & 1 & Bagerhat sadar \\
\hline \multirow[t]{2}{*}{30} & Wheat-Jute-Fallow & 10 & 0.00 & 1 & Dumuria \\
\hline & Total & 1095 & 0.30 & & \\
\hline
\end{tabular}

Table 8. Distribution of the most dominant Fallow-Fallow-T. Aman cropping pattern in Khulna region, 2014-15.

\begin{tabular}{llccc}
\hline & Upazila & Area (ha) & \% of upazila NCA & \% of the pattern in region \\
\hline 01 Morrelganj & 18700 & 67.50 & 19.30 \\
02 Dacope & 16100 & 85.78 & 16.62 \\
03 Shyamnagar & 12000 & 68.61 & 12.38 \\
04 Koyra & 10500 & 67.36 & 10.84 \\
05 & Batiaghata & 5500 & 30.78 & 5.68 \\
06 & Kaliganj & 5000 & 27.09 & 5.16 \\
07 & Dumuria & 4900 & 16.61 & 5.06 \\
08 Rampal & 4400 & 46.81 & 4.54 \\
09 & Assasuni & 4100 & 35.65 & 4.23 \\
10 Bagerhat sadar & 3800 & 22.82 & 3.92 \\
11 Sarankhola & 3800 & 40.17 & 3.92 \\
12 Paikgachha & 3000 & 17.53 & 3.10 \\
13 Mongla & 2000 & 74.07 & 2.06 \\
14 & Rupsha & 2000 & 24.51 & 2.06 \\
15 Kachua & 700 & 7.67 & 0.72 \\
16 & Fakirhat & 300 & 3.41 & 0.31 \\
17 Debhata & 100 & 1.47 & 0.10 \\
\hline Khulna region & 96900 & 27.24 & 100.00 \\
\hline
\end{tabular}




\section{Second dominant cropping pattern}

Boro-Fallow-T. Aman cropping pattern ranked the second position in the region distributed to 24 upazilas out of 25 . However, their magnitude of contribution to the region was different, ranging 0.02 (Dacope) to $18.65 \%$ (Satkhira sadar) of the total area for the pattern in the region. The major share was from Satkhira sadar, Dumuria, Kalaroa, Assasuni, Kaliganj, Bagerhat sadar, Tala and Chitalmari upazilas (Table 9). In the country-wide compilation of data it was observed that Boro-F-T. Aman was the most dominant cropping pattern in Bangladesh covering 2.31 million ha $(27 \%$ of NCA in the country) with its distribution in 426 upazilas of 63 districts (Nasim et al., 2017).

\section{Third dominant cropping pattern}

The third cropping pattern in the Khulna region was Boro-Fish which is distributed to 17 upazilas with different level of contribution (0.32 to $21.66 \%)$. The major share of the cropping pattern from Chitalmari, Dumuria, Rupsha,
Tala, Kalaroa, Mollahat, Terokhada, Bagerhat sadar, Fakirhat, Rampal and Phultala (Table 10). In non-saline or low saline ghers water stagnation in Kharif-II season restricted rice production creates opportunity for practicing Boro-Fish. Here year round vegetables are frequently grown as dyke crop. On the other hand, T. Aman-Fish is the dominant cropping pattern in saline ghers. Rice-fish is an exceptional enterprise in Khulna region. Some constraints like salinity and water-stagnation and some opportunities like availability of modern technologies for fish culture and its export facilities are the driving forces for the enterprise (FAO, 1988).

\section{Fourth dominant cropping pattern}

Boro-Fallow-Fallow, identified as fourth dominant cropping pattern, has occupied 27,850 hectares representing $7.83 \%$ share of NCA in Khulna region (Table 11). This pattern is distributed over 18 upazilas where Dumuria ranked in the top position. This upazila has

Table 9. Distribution of the ${ }^{\text {nd }}$ dominant Boro-Fallow-T. Aman cropping pattern in Khulna region, 2014-15.

\begin{tabular}{|c|c|c|c|c|}
\hline & Upazila & Area (ha) & $\%$ of upazila NCA & $\%$ of the pattern in region \\
\hline 01 & Satkhira sadar & 15000 & 55.73 & 18.65 \\
\hline 02 & Dumuria & 7400 & 25.09 & 9.20 \\
\hline 03 & Kalaroa & 6850 & 39.06 & 8.52 \\
\hline 04 & Assasuni & 5600 & 48.70 & 6.96 \\
\hline 05 & Kaliganj & 4600 & 24.92 & 5.72 \\
\hline 06 & Bagerhat sadar & 4500 & 27.02 & 5.60 \\
\hline 07 & Tala & 4500 & 19.80 & 5.60 \\
\hline 08 & Chitalmari & 3800 & 28.11 & 4.73 \\
\hline 09 & Batiaghata & 2950 & 16.51 & 3.67 \\
\hline 10 & Fakirhat & 2900 & 32.95 & 3.61 \\
\hline 11 & Kachua & 2800 & 30.67 & 3.48 \\
\hline 12 & Debhata & 2800 & 41.09 & 3.48 \\
\hline 13 & Mollahat & 2500 & 15.45 & 3.11 \\
\hline 14 & Koyra & 2000 & 12.83 & 2.49 \\
\hline 15 & Rupsha & 2000 & 24.51 & 2.49 \\
\hline 16 & Phultala & 1900 & 38.92 & 2.36 \\
\hline 17 & Morrelganj & 1800 & 6.50 & 2.24 \\
\hline 18 & Dighalia & 1700 & 29.72 & 2.11 \\
\hline 19 & Shyamnagar & 1600 & 9.15 & 1.99 \\
\hline 20 & Paikgachha & 1500 & 8.76 & 1.87 \\
\hline 21 & Rampal & 1200 & 12.77 & 1.49 \\
\hline 22 & Terokhada & 400 & 4.21 & 0.50 \\
\hline 23 & Sarankhola & 100 & 1.06 & 0.12 \\
\hline \multirow[t]{2}{*}{24} & Dacope & 20 & 0.11 & 0.02 \\
\hline & Khulna region & 80420 & 22.61 & 100.00 \\
\hline
\end{tabular}


Table 10. Distribution of the $3^{\text {rd }}$ dominant Boro-Fish cropping pattern in Khulna region, 2014-15.

\begin{tabular}{llccc}
\hline & Upazila & Area $(\mathrm{ha})$ & \% of upazila NCA & \% of the pattern in region \\
\hline 01 & Chitalmari & 6800 & 50.30 & 21.66 \\
02 & Dumuria & 3900 & 13.22 & 12.42 \\
03 & Rupsha & 3400 & 41.67 & 10.83 \\
04 & Tala & 3000 & 13.20 & 9.55 \\
05 & Kalaroa & 2600 & 14.82 & 8.28 \\
06 & Mollahat & 1800 & 11.13 & 5.73 \\
07 & Terokhada & 1700 & 17.90 & 5.41 \\
08 & Bagerhat sadar & 1500 & 9.01 & 4.78 \\
09 & Phultala & 1500 & 30.73 & 4.78 \\
10 & Rampal & 1400 & 14.89 & 4.46 \\
11 & Fakirhat & 1300 & 14.77 & 4.14 \\
12 & Dighalia & 800 & 13.99 & 2.55 \\
13 & Batiaghata & 500 & 2.80 & 1.59 \\
14 & Debhata & 500 & 7.34 & 1.59 \\
15 & Kachua & 400 & 4.38 & 1.27 \\
16 & Satkhira sadar & 200 & 0.74 & 0.64 \\
17 & Assasuni & 100 & 0.87 & 0.32 \\
\hline & Khulna region & 31400 & 8.83 & 100.00 \\
\hline
\end{tabular}

4,400 ha area for single Boro which is only $14.92 \%$ of upazila NCA. Fakirhat upazila ranks in fifth position with 2,800 ha area for this pattern, however, this upazila has the biggest share $(31.82 \%)$ of its NCA. This pattern is frequent and concurrently suffer from early flash in April and cold injury at the reproductive stage. Diversified cropping pattern may be resort for the farmer as a coping strategy with flood related risk (Mandal and Bezbaruah, 2013) but scope of diversification is limited due to environmental and climatic condition (FAO, 1988).

\section{Fifth dominant cropping pattern}

Fifth dominant cropping pattern Fish-T. Aman had been covering 20,400 hectares representing $5.74 \%$ share of NCA in Khulna region (Table 12). This pattern is distributed in only eight upazilas where Paikgachha ranked in top position contributing $41.67 \%$ of the pattern area in the region. This upazila had 8,500 ha area for Fish-T. Aman pattern which is about one-half of upazila NCA. Kaliganj upazila had the $2^{\text {nd }}$ largest area 3,500 ha for this cropping and this upazila had allotted also the $2^{\text {nd }}$ biggest share $(18.96 \%)$ of its NCA.

\section{Crop diversity and cropping intensity}

Number of cropping pattern is a gross indicator of crop diversity. The highest number of cropping patterns were recorded in Kalaroa (26) followed by Tala (24), Dumuria (22), Kachua (21), Mollahat (20). These upazilas are in non-saline areas where Kalaroa is mainly high to medium high land ecosystem. The number of cropping patterns in Rampal, Rupsha, Koyra, Dacope, Tekokhada, Shyamnagar, were 8, 10, 11, 11, 12 and 13, respectively. In contrast, the lowest number of cropping patterns were reported in Mongla (5). Higher number of cropping pattern is generally related to higher diversity indices for cropping pattern. The upazilas having lower number of cropping pattern were related to either salinity or water-logging or both. The calculated diversity indices (CDI) for cropping pattern are presented in Table 13. The overall crop diversity index for the region was 0.93 . The highest CDI was in Tala (0.95) followed by Mollahat and Kachua and Dumuria and the lowest CDI was in Dacope (0.42) which was close to Mongla $(0.48 \%)$. The average cropping intensity (CI) of the Khulna region was $171 \%$. The lowest CI was recorded in Mongla (101\%) and the highest was in Kalaroa (224\%). The cropping intensity of Satkhira sadar, Debhata and Chitalmari were 
Table 11. Distribution of the $4^{\text {th }}$ dominant Boro-Fallow-Fallow cropping pattern in Khulna region, $2014-15$.

\begin{tabular}{llrcc}
\hline & Upazila & Area (ha) & \% of upazila NCA & \% of the pattern in region \\
\hline 01 & Dumuria & 4400 & 14.92 & 15.80 \\
02 & Mollahat & 4200 & 25.96 & 15.08 \\
03 & Tala & 4000 & 17.60 & 14.36 \\
04 & Bagerhat sadar & 2900 & 17.41 & 10.41 \\
05 & Fakirhat & 2800 & 31.82 & 10.05 \\
06 & Rampal & 1900 & 20.21 & 6.82 \\
07 & Chitalmari & 1000 & 7.40 & 3.59 \\
08 & Kalaroa & 1000 & 5.70 & 3.59 \\
09 & Satkhira & 1000 & 3.72 & 3.59 \\
10 & Kachua & 800 & 8.76 & 2.87 \\
11 & Dighalia & 700 & 12.24 & 2.51 \\
12 & Paikgachha & 700 & 4.09 & 2.51 \\
13 & Terokhada & 700 & 7.37 & 2.51 \\
14 & Debhata & 600 & 8.80 & 2.15 \\
15 & Phultola & 500 & 10.24 & 1.80 \\
16 & Assasuni & 400 & 3.48 & 1.44 \\
17 & Koyra & 150 & 0.96 & 0.54 \\
18 & Morrelganj & 100 & 0.36 & 0.36 \\
\hline & Khulna region & 27850 & 7.83 & 100.00 \\
\hline
\end{tabular}

Table 12. Distribution of the $5^{\text {th }}$ dominant Fish-T. Aman cropping pattern in Khulna region, 2014-15.

\begin{tabular}{llrcc}
\hline & Upazila & Area (ha) & \% of upazila NCA & \% of the pattern in region \\
\hline 1 & Paikgachha & 8500 & 49.66 & 41.67 \\
2 & Kaliganj & 3500 & 18.96 & 17.16 \\
3 & Tala & 2500 & 11.00 & 12.25 \\
4 & Koyra & 2000 & 12.83 & 9.80 \\
5 & Shyamnagar & 2000 & 11.44 & 9.80 \\
6 & Morrelganj & 1500 & 5.41 & 7.35 \\
7 & Batiaghata & 300 & 1.68 & 1.47 \\
8 & Debhata & 100 & 1.47 & 0.49 \\
\hline & Khulna region & 20400 & 5.74 & 100.00 \\
\hline
\end{tabular}

221, 219 and $200 \%$, respectively. The lower CI was related to the higher salinity and waterlogging in the respective upazila. Shahidullah et al. (2006) also found the lowest CI in the salinity affected upazilas of eastern coastal Region of Bangladesh. Diversified cropping pattern may enabled the farmers compulsion of extracting the maximum possible utilization of land in the flood free period (Mandal and Bezbaruah, 2013). Our findings agree with the results of Singh and Sidhu (2006) and Tscharntke et al., 2005 and 2007).

\section{CONCLUSION}

The cropping intensity of the Khulna region was much lower than the national average. Single T. Aman, Boro-Fallow-T. Aman, BoroFish, Boro-Fallow-Fallow, Fish-T. Aman were the major cropping patterns in the region. The non-rice based cropping patterns were few with less area coverageleads to the challenge of food and nutritional security for Khulna region. Based on the findings of the study, the following recommendations were made. 
Table 13. Crops and cropping pattern and their diversity index in Khulna region, 2014-15.

\begin{tabular}{|c|c|c|c|c|c|c|}
\hline & Upazila & $\begin{array}{c}\text { No. of identified } \\
\text { pattern }\end{array}$ & No. of crop & $\begin{array}{l}\text { Diversity index for } \\
\text { cropping pattern }\end{array}$ & $\begin{array}{l}\text { Crop diversity } \\
\text { index (CDI) }\end{array}$ & C.I. $(\%)$ \\
\hline 01 & Bagerhat sadar & 16 & 13 & 0.81 & 0.89 & 171 \\
\hline 02 & Chitalmari & 17 & 16 & 0.66 & 0.83 & 200 \\
\hline 03 & Fakirhat & 17 & 15 & 0.76 & 0.87 & 167 \\
\hline 04 & Kachua & 21 & 18 & 0.86 & 0.92 & 185 \\
\hline 05 & Mollahat & 20 & 17 & 0.86 & 0.93 & 176 \\
\hline 06 & Mongla & 05 & 05 & 0.43 & 0.48 & 103 \\
\hline 07 & Morrelganj & 18 & 16 & 0.53 & 0.73 & 132 \\
\hline 08 & Rampal & 08 & 08 & 0.70 & 0.81 & 135 \\
\hline 09 & Sarankhola & 12 & 10 & 0.67 & 0.82 & 166 \\
\hline 10 & Batiaghata & 16 & 15 & 074 & 0.86 & 172 \\
\hline 11 & Dacope & 11 & 08 & 0.26 & 0.42 & 114 \\
\hline 12 & Dighalia & 17 & 12 & 0.84 & 0.90 & 177 \\
\hline 13 & Dumuria & 22 & 17 & 0.67 & 0.91 & 169 \\
\hline 14 & Phultala & 14 & 12 & 0.73 & 0.86 & 192 \\
\hline 15 & Koyra & 11 & 10 & 0.51 & 0.71 & 133 \\
\hline 16 & Paikgachha & 12 & 09 & 0.70 & 0.83 & 181 \\
\hline 17 & Rupsha & 10 & 09 & 0.71 & 0.83 & 175 \\
\hline 18 & Terokhada & 12 & 10 & 0.81 & 0.85 & 157 \\
\hline 19 & Assasuni & 18 & 12 & 0.63 & 0.79 & 169 \\
\hline 20 & Debhata & 15 & 10 & 0.79 & 0.91 & 219 \\
\hline 21 & Kalaroa & 26 & 19 & 0.81 & 0.92 & 224 \\
\hline 22 & Kaliganj & 15 & 09 & 0.81 & 0.91 & 179 \\
\hline 23 & Satkhira sadar & 21 & 15 & 0.67 & 0.86 & 221 \\
\hline 24 & Shyamnagar & 13 & 11 & 0.51 & 0.71 & 133 \\
\hline \multirow[t]{2}{*}{25} & Tala & 24 & 17 & 0.88 & 0.95 & 198 \\
\hline & Khulna region & 92 & 27 & 0.86 & 0.93 & 171 \\
\hline
\end{tabular}

- Initiative to be taken to increase productivity of exclusive rice based cropping pattern along with recommended crop management packages.

- Short to medium duration high yielding potential Boro rice varieties suitable for Boro-Fish cropping pattern and waterlogging tolerant non-lodging T. Aman varieties and suitable fish species with improved production practices to be extensively adopted for increasing system productivity.

- The cropping patterns with minor area coverage particularly Rice-Fish systems along with year round vegetable production on the dyke should be taken as priority technology for up-scaling in south west region.
- The upazilas having higher cropping pattern index might be studied in depth to extrapolate potential cropping patterns to other upazilas of similar environments.

- Research initiative should be taken to develop a mixing model of surface water and ground water with mild salinity for safe production of multiple crops.

\section{REFERENCES}

Agrawal, D J and A H Kassam. 1976. The importance of multiple cropping in increasing world food supplies. A special publication No. 27, American Society of Agronomy, Madison, Wisconsin. pp. 2-3.

Alam, M S. 1994. Optimum cropping patterns of the small farmers under risk: a micro level study in Bangladesh. Ph.D. thesis, Department of Agricultural Economics, Bangladesh Agricultural University, Mymensingh. 
BBS (Bangladesh Bureau of Statistics). 2014. Statistical Yearbook of Bangladesh. Statistics Division, Ministry of Planning, Government of the People's Republic of Bangladesh.

FAO, 1988. Land Resources Appraisal of Bangladesh for Agricultural Development- Report 2: Agroecological regions of Bangladesh. Food and Agriculture Organization of the United Nations, Rome, Italy, $570 \mathrm{p}$.

Gadge, S S. 2003. Influence of changes in cropping pattern on farmers' economic status. Indian J. Ext. Edu. 39(1\&2): 99-101.

Kshirsagar, K G, S Pandey and M R Bellon. 1997. Farmers' perception, varietal characteristics and technology adoption: the case of rainfed village in eastern India. Discussion paper 5/97. Social Sciences Division, International Rice Research Institute. Los Baňos, Laguna, Philippines.

Mandal, R and M P Bezbaruah. 2013. Diversification of cropping pattern: its determinants and role in flood affected agriculture of Assam Plains. Indian J. Agric. Econ. 68(2): 169-181.

MoA and FAO. 2013. Master Plan for Agricultural Development in the Southern Region of Bangladesh, Ministry of Agriculture, Government of the People's Republic of Bangladesh.

Nasim, M, S M Shahidullah, A Saha, M A Muttaleb, T L Aditya, M A Ali and M S Kabir. 2017. Distribution of Crops and Cropping Patterns in Bangladesh. Bangladesh Rice J. 21(2): 1-55.
Neena, D. 1998. Interstate variation in cropping pattern in India. Indian J. Regi. Sci. 30(2): 57-69.

Rahman, M M and M Ahsan. 2011. Salinity constraints and agricultural productivity in coastal saline area of Bangladesh. Soil Resources in Bangladesh: Assessment and Utilization, Soil Resources Development Institute (SRDI), Farmgate, Dhaka 1215, Bangladesh.

Rashid, M H, A H Khan and M M Alam. 2005. Cropping systems dynamics in greater Khustia. J. Bangladesh Agril. Univ. 3(2): 213-238.

Shahidullah, S M, M S A Talukder, M S Kabir, A H Khan and N E Elahi. 2006. Cropping patterns in the South East Coastal Region of Bangladesh. J. Agric. Rural Dev. 4(1\&2): 53-60.

Shriar, A J. 2000. Agricultural intensity and its measurement in frontier regions.Agroforestry Systems.49(3): 301-318.

Singh, J and R S Sidhu. 2006. Accounting for impact of environmental degradation in agriculture of Indian Punjab. Agric. Economics Res. Rev. 19: 37-48.

SRDI, 2010. Saline Soils of Bangladesh. Soil Resource Development Institute, Farmgate, Dhaka-1215. 55p.

Tscharntke, T, R Bommarco, Y Clough, T O Crist, D Klein, T A Rand, J M Tylianakis, S vanNouhuys, and S Vidal. 2007. Conservation biological control and enemy diversity on a landscape scale. Biol. Control. 43: 294-309.

Tscharntke, T, A M Klein, A Kruess, I S Dewenter, and C Thies. 2005. Landscape perspectives on agricultural intensification and biodiversity-ecosystem service management. Ecol. Lett. 8: 857-874. 
Appendix 1. List of cropping patterns in Khulna region, 2014-15.

\begin{tabular}{|c|c|c|c|c|c|}
\hline & Cropping pattern & Area (ha) & & Cropping pattern & Area (ha) \\
\hline 01 & Fallow-Fallow-T. Aman & 96900 & 32 & Vegetab-Jute-T. Aman & 760 \\
\hline 02 & Boro-Fallow-T. Aman & 80420 & 33 & Vegetab-Aus-T. Aman & 720 \\
\hline 03 & Boro-Fish & 31400 & 34 & Vegetab-Fallow-Fallow & 535 \\
\hline 04 & Boro-Fallow-Fallow & 27850 & 35 & Garlic-Jute-T. Aman & 530 \\
\hline 05 & Fish-T. Aman & 20400 & 36 & Fallow-Vegetab-T. Aman & 500 \\
\hline 06 & Vegetab-Vegetab-Vegetab & 12060 & 37 & Sunflower-Fallow-T. Aman & 490 \\
\hline 07 & Fallow-Sesame-T. Aman & 10170 & 38 & Potato-Fallow-T. Aman & 460 \\
\hline 08 & Grasspea-Fallow-T. Aman & 8390 & 39 & Mustard-Aus-T. Aman & 450 \\
\hline 09 & Boro-Aus-Fallow & 7670 & 40 & Chilli-Jute-T. Aman & 410 \\
\hline 10 & Boro-Fallow-T. Aman+Fish & 5410 & 41 & Fallow-B.Aus+B.Aman & 400 \\
\hline 11 & Boro-Aus-T. Aman & 3895 & 42 & Grasspea-Aus-T. Aman & 350 \\
\hline 12 & Fallow-B.Aman & 3520 & 43 & S.Potato-Fallow-T. Aman & 350 \\
\hline 13 & Boro-B.Aman & 3500 & 44 & Chilli-Vegetab-Fallow & 340 \\
\hline 14 & Mustard-Jute-T. Aman & 3210 & 45 & Mustard-Sesame-T. Aman & 310 \\
\hline 15 & Boro-Jute-Fallow & 2800 & 46 & Wheat-Aus-T. Aman & 300 \\
\hline 16 & Mustard-Boro-T. Aman & 2470 & 47 & Lentil-Fallow-T. Aman & 280 \\
\hline 17 & Vegetab-Vegetab-Fallow & 2420 & 48 & Maize-Fallow-T. Aman & 260 \\
\hline 18 & Fallow-Aus-T. Aman & 2220 & 49 & Boro-Vegetab-T. Aman & 250 \\
\hline 19 & Fallow-Fallow-T. Aman+Fish & 2200 & 50 & Potato-Aus-T. Aman & 250 \\
\hline 20 & W.Melon-Fallow-T. Aman & 2100 & 51 & Potato-Jute-Fallow & 250 \\
\hline 21 & Wheat-Jute-T. Aman & 1510 & 52 & Onion-Fallow-T. Aman & 220 \\
\hline 22 & Lentil-Jute-T. Aman & 1390 & 53 & Chilli-Fallow-T. Aman & 210 \\
\hline 23 & Potato-Vegetab-T. Aman & 1310 & 54 & Mustard-Aus-Fallow & 200 \\
\hline 24 & Mungbean-Fallow-T. Aman & 1280 & 55 & Mustard-Jute-Fallow & 200 \\
\hline 25 & Vegetab-Fallow-T. Aman & 1200 & 56 & W.Melon-Fallow-Fallow & 200 \\
\hline 26 & Fallow-Jute-T. Aman & 1100 & 57 & Grasspea-Mungbean-T. Aman & 170 \\
\hline 27 & Potato-Jute-T. Aman & 1100 & 58 & Vegetab-Aus-Fallow & 150 \\
\hline 28 & Vegetab-Vegetab-T. Aman & 960 & 59 & Garlic-Fallow-T. Aman & 130 \\
\hline 29 & Mustard-Fallow-T. Aman & 940 & 60 & Potato-S.gourd-Aus & 130 \\
\hline 30 & Onion-Jute-T. Aman & 820 & 61 & Boro-Vegetab(Float/Norm) & 120 \\
\hline \multirow[t]{2}{*}{31} & Grasspea-Jute-T. Aman & 780 & 62 & Mustard-Boro-Jute-T. Aman & 110 \\
\hline & & & $63-92$ & Other 30 patterns (Table 7) & 1095 \\
\hline
\end{tabular}


